\title{
Efficiency of Dietary Supplementation of Flavonoid (Quercetin), Vegetable Oil and Its Combination on Growth Traits and Feed Conversion in Broilers
}

\author{
A.B. Parmar ${ }^{1}$, V.R. Patel ${ }^{2 *}$ and N.S. Dangar ${ }^{3}$ \\ ${ }^{1}$ Animal Nutrition Research Station, College of Veterinary Science \& Animal husbandry, Anand Agricultural University, \\ Anand, Gujarat, INDIA \\ ${ }^{2}$ Department of Animal Nutrition, College of Veterinary Science E Animal Husbandry, Navsari Agricultural University, \\ Navsari, Gujarat, INDIA \\ ${ }^{3}$ Livestock Research Station, Navsari Agricultural University, Navsari, Gujarat, INDIA \\ *Corresponding author: VR Patel; E-mail: vrpatel@nau.in
}

Received: 30 May, 2020

Revised: 28 July, 2020

Accepted: 31 July, 2020

\begin{abstract}
The study was conducted to investigate the efficiency of dietary supplementation of Flavonoid (Quercetin) compound, vegetable oil and its combination on feed intake, growth traits and feed conversion in broiler chickens. Four dietary treatments were assigned in to 192 Vencob-400 strain broiler chicks for the 35 days duration $\left(7^{\text {th }}-42^{\text {nd }}\right.$ days). The treatments were control (T1) without any supplementation, whereas T2, T3 and T4 supplemented with Quercetin $\left(1 \mathrm{~g} \mathrm{~kg}^{-1}\right)$, vegetable oil ( $>10 \%$ of ME recommendation) and combination of Quercetin with vegetable oil, respectively. Each group comprised of four replicates (12 birds in each). All the treatment groups were fed similar corn soya based basal diet. Daily and weekly feed intake throughout the experimental period was found comparable among the dietary treatment groups except the period of $4^{\text {th }}$ week, where higher $(\mathrm{P}<0.05)$ feed intake was observed in control (T1). During starter phase weekly body weight gain ( $\mathrm{g} / \mathrm{bird} / \mathrm{week})$ and weekly growth rate $(\mathrm{g} / \mathrm{bird} / \mathrm{d})$ was significantly $(\mathrm{P}<0.01)$ differ amongst the group, which was highest in $\mathrm{T} 4$; while these parameters were found comparable in finisher phase. However, the cumulative weight gains and cumulative growth rate were significantly $(\mathrm{P}<0.01)$ higher in T3 and T4 group. Similarly, Quercetin supplementation (T2) had also revealed higher cumulative weekly weight gain and growth rate over control group $(\mathrm{P}<0.01)$. The feed conversion ratio was revealed better $(\mathrm{P}<0.05)$ in $\mathrm{T} 4$ group during $4^{\text {th }}$ and $6^{\text {th }}$ week and also for overall experiment. Thus, the supplementation of Quercetin or vegetable oil or its combination in broilers had shown a better growth performance and improvement in feed conversion ratio.
\end{abstract}

\section{HIGHLIGHTS}

(0 Growth performance was better due to supplementation of Flavonoid (Quercetin) or vegetable oil or its combination.

( The FCR was improved in broilers fed combination of Flavonoid (Quercetin) and vegetable oil.

Keywords: Broilers, Feed conversion ratio, Growth, Quercetin, Vegetable oil

Poultry industry is recognized as one of the phenomenal industries due to its low cost investment, early assure return, limited land intake and short generation intervals. Progressively it becomes more popular to fight against unemployment, poverty and malnutrition (Yadav, 2018). Within the poultry sector, two thirds of the output (about 66.7 per cent) is contributed by the broiler sector and the other third (about 33.3 per cent) by egg production (BAHS, 2017). Current intensive poultry sector aims to produce the ready broiler chicken within six weeks of age, as commercial broiler bird having a dynamic growth, development process and is one of the fastest growing birds (Patane et al., 2017). Feed contributes a 75\% production

How to cite this article: Parmar, A.B., Patel, V.R. and Dangar, N.S. (2020). Efficiency of dietary supplementation of flavonoid (quercetin), vegetable oil and its combination on growth traits and feed conversion in broilers. $J$. Anim. Res., 10(4): 557-562.

Source of Support: None; Conflict of Interest: None 
cost and is the major influencing factor in broiler rearing. Inclusion of oil sources in poultry ration has often been practiced for early growth, in addition oil incorporation raised the energy density of diet, absorption of fat soluble vitamins, hydrolysis of essential fatty acids and resultant enhanced the energy consumption (Parmar et al., 2019a).

Flavonoids are polyphenolic group of compounds, created an eye catching interest owing to its multiple biological actions and suited the best as a "functional phyto-ingredient" in the absence of banned antibiotic growth promoters for animals and poultry birds (Parmar et al., 2019b). Quercetin is a flavonoid compound of class flavonols and has very strong antioxidant potential, along with anti-inflammatory, gut health promoter, growth enhancers and immune modulating properties (Sikder et al., 2014). Poultry birds are very sensitive to various physiological and metabolic stresses thus need to be supplied a plant based additives with having different biological activities. Therefore, considering the facts, the study was conducted to evaluate the effect of Quercetin, as a flavonoid compound and the vegetable oil supplementation on feed consumption, growth traits and feed conversion ratio of broiler chickens.

\section{MATERIALS AND METHODS}

The experiment was carried out at Department of Animal Nutrition, College of Veterinary Science \& Animal Husbandry, Navsari Agricultural University, Navsari, Gujarat with using 192 Vencob-400 strain Broilers (Gallus gallus domesticus). The experiment was conducted with the standard rules and permission of Institutional Animal Ethics Committee (IAEC). One day old chicks were provided with one week adaptation period and after that from the $7^{\text {th }}$ day onwards birds were assigned in to four dietary treatment groups, each group comprises four replicates which contains 12 birds in each (48 Birds Group $\left.^{-1}\right)$. All the birds were fed with corn-soya based basal diet formulated as per BIS (2007) recommendation for starter (8-21 days) and finisher phase ration (2242 days), respectively in all the treatment groups. The birds under control group (T1) were fed only basal diet without any supplementation, while other three treatment groups were fed similar basal diet along with Quercetin ( $\left.1 \mathrm{~g} \mathrm{Kg}^{-1}\right)$, Vegetable oil ( $>10 \%$ of ME recommendation) and combination of Quercetin $\left(1 \mathrm{~g} \mathrm{Kg}^{-1}\right)+$ Vegetable oil
$(>10 \%$ of $\mathrm{ME}$ than recommendation) in $\mathrm{T} 2, \mathrm{~T} 3$ and $\mathrm{T} 4$, respectively. The treatment diets were supplemented for 35 days duration (7-42 days of age). The basal diet was formulated with maize $(50 \%)$, maize gluten $(7.3 \%)$, De-oiled rice bran $(9.0 \%)$, Rice polish $(5.0 \%)$, de-oiled soya cake $(8.7 \%)$, ground nut cake $(9.0 \%)$, Protolive $(7.9 \%)$ and mineral mixture, Di-calcium phosphate, salt, Biometh, lysine, toxin binder, choline and Meriplex $(2.9 \%)$. Details of treatment regimen are given in Table 1. The nutritional composition of experimental feed was estimated according AOAC (2008). The birds were provided with similar environmental and managemental condition throughout entire experimental period in all the treatment groups. Clean, fresh, wholesome ad libitum drinking water was provided to all experimental birds throughout the experimental period. Commercially available hydrogenated vegetable oil was acquired from local market and the Quercetin ( $\geq 95 \%$ (HPLC) solid (Lot\#SLBS2349V)2(3,4-Dihydroxyphenyl)3,5,7-trihydroxy-4h-1-benzopyran-4one, 3,3', 4', 5,6 pentahydroxyflavone) natural powder was acquired from Sigma Aldrich (P) Ltd.

Table 1: Feeding and treatment regimen of broiler chickens under experiment

\begin{tabular}{|c|c|c|}
\hline $\begin{array}{l}\text { Treatment } \\
\text { Group }\end{array}$ & Diet & Supplementation \\
\hline I: T1 (CON) & Basal diet & None \\
\hline II: T2 (Q) & Basal diet & Quercetin $@ 1.0 \mathrm{~g} / \mathrm{kg}$ of feed \\
\hline III: T3 (HFD) & Basal diet & $\begin{array}{l}\text { *Vegetable oil @ (Starter diet-34 } \\
\text { g/kg of feed, Finisher diet-35 g/kg } \\
\text { of feed) }\end{array}$ \\
\hline IV: T4 (HFD+Q) & Basal diet & $\begin{array}{l}\text { *Vegetable oil @ (Starter diet-34 } \\
\text { g/kg of feed, Finisher diet-35 g/ } \\
\text { kg of feed)+ Quercetin @ } 1.0 \mathrm{~g} / \\
\text { kg of feed }\end{array}$ \\
\hline
\end{tabular}

(T: Treatment; CON: Control; Q: Quercetin; HFD- High fat diet; $*>10 \%$ of ME recommendation of BIS, 2007).

Daily weighted quantity of feed was offered in each pen and leftover feed was recorded to estimate the voluntary feed intake. At weekly interval, the difference in weight of feed offered and that of leftover indicated consumption of feed by particular group of birds. Average feed intake in gram/ chick/week was calculated by dividing the total amount of feed consumed by the number of chicks in the particular 
pen for respective week. Cumulative feed consumption for experimental period was worked out based on voluntary feed intake of birds. Individual body weight of all the chicks was recorded with standard electronic weighing balance (Scale-Tec, Digital Weighing Balance) on the day of their procurement, at beginning of experimental period and thereafter at weekly interval for each replication/ treatment groups during experimental period. The average weekly body weight gain was calculated by subtracting the body weight of previous week from that of current. Further, average daily body weight gain and cumulative body weight gain were also worked out accordingly. Feed conversion ratio (FCR) was calculated based on the amount of feed consumed to unit weight gain by standard formula.

The data were analyzed statistically using statistical significance using package for the social sciences (SPSS, version 20.0 Chicago, USA) following the Duncan's multiple range test for comparisons of means (Duncan, 1955).

\section{RESULTS AND DISCUSSION}

\section{Feed intake}

The average weekly feed consumption (g/bird/week) and daily feed consumption (g/bird/day) data are presented in Table 2. Daily and weekly feed intake was comparable throughout the experimental period except $4^{\text {th }}$ week. During $4^{\text {th }}$ week, the feed intake was significantly $(\mathrm{P}<0.05)$ low in Quercetin supplemented group (T2) as compared to control (T1). However, values in vegetable oil supplemented group either alone (T3) or in combination with Quercetin (T4) was comparable with T1 and T2. This indicated that supplementation of $10 \%$ high fat than the BIS (2007) recommendations didn't make any significant difference on feed consumption of broilers. Moreover, data pertaining to starter phase and finisher phase feeding was also revealed alike. Similarly, comparable feed intake at different level of oil supplementation (Olive oil (2\%, $5 \%)$, Palm oil $(2 \%, 4 \%, 6 \%)$, Sunflower oil $(2 \%, 4 \%$, $6 \%$ ) was reported in previous studies (Zhang et al., 2013; Khatun et al., 2018). Feed intake shown apparently lower in oil supplemented groups that might be due to the greater impact of higher energy- yielding capacity of saturated fatty acid (SFA), however fatty acid profile of oil sources might have influenced feed intake of broiler birds (Attia et al., 2020).

The feed intake of birds was not influenced on incorporation of Quercetin (flavonoid compound) as anti-oxidant and/or lypolytic agent with (T4) or without fat (T2). This finding

Table 2: Effects of dietary Flavonoid (Quercetin) and vegetable oil supplementation on weekly feed intake and daily feed intake in broilers

\begin{tabular}{|c|c|c|c|c|c|c|}
\hline \multirow{2}{*}{ Week } & \multicolumn{4}{|c|}{ Treatment Group } & \multirow{2}{*}{-SEM } & \multirow{2}{*}{ P-Value } \\
\hline & T1 & T2 & T3 & T4 & & \\
\hline \multicolumn{7}{|c|}{ Weekly feed intake (g/bird/d) } \\
\hline 2 & $341.71 \pm 8.96$ & $347.17 \pm 16.76$ & $346.32 \pm 5.86$ & $350.78 \pm 4.11$ & 4.618 & 0.937 \\
\hline 3 & $622.55 \pm 28.7$ & $616.71 \pm 14.57$ & $639.75 \pm 11.66$ & $595.79 \pm 13.60$ & 9.183 & 0.439 \\
\hline Starter & $482.13 \pm 18.80$ & $481.94 \pm 11.83$ & $493.03 \pm 7.30$ & $473.28 \pm 8.56$ & 5.567 & 0.741 \\
\hline 4 & $977.89 \pm 38.27^{\mathrm{a}}$ & $866.86 \pm 35.42^{b}$ & $902.77 \pm 17.40^{\mathrm{ab}}$ & $872.21 \pm 37.30^{\mathrm{ab}}$ & 18.747 & 0.051 \\
\hline 5 & $1088.24 \pm 23.62$ & $1022.88 \pm 35.46$ & $1059.02 \pm 20.28$ & $1040.19 \pm 36.24$ & 14.704 & 0.477 \\
\hline 6 & $1091.18 \pm 10.82$ & $1119.33 \pm 59.43$ & $1011.49 \pm 30.10$ & $1030.34 \pm 23.74$ & 19.599 & 0.168 \\
\hline Finisher & $1052.44 \pm 22.27$ & $1003.03 \pm 30.39$ & $991.10 \pm 12.05$ & $980.91 \pm 31.10$ & 13.299 & 0.244 \\
\hline \multicolumn{7}{|c|}{ Daily feed intake (g/bird/d) } \\
\hline 2 & $48.81 \pm 1.27$ & $49.59 \pm 2.39$ & $49.47 \pm 0.83$ & $50.11 \pm 0.58$ & 0.659 & 0.937 \\
\hline 3 & $88.93 \pm 4.1$ & $88.10 \pm 2.08$ & $91.39 \pm 1.66$ & $85.11 \pm 1.94$ & 1.310 & 0.439 \\
\hline Starter & $68.87 \pm 2.68$ & $68.85 \pm 1.69$ & $70.43 \pm 1.04$ & $67.61 \pm 1.22$ & 0.836 & 0.741 \\
\hline 4 & $139.69 \pm 5.46^{\mathrm{a}}$ & $123.84 \pm 5.05^{b}$ & $128.96 \pm 2.48^{\mathrm{ab}}$ & $124.60 \pm 5.32^{\mathrm{ab}}$ & 2.678 & 0.081 \\
\hline 5 & $155.46 \pm 3.37$ & $146.12 \pm 5.06$ & $151.28 \pm 2.89$ & $148.59 \pm 5.17$ & 2.100 & 0.477 \\
\hline 6 & $155.88 \pm 1.54$ & $159.90 \pm 8.49$ & $144.50 \pm 4.30$ & $147.19 \pm 3.39$ & 2.800 & 0.168 \\
\hline Finisher & $150.34 \pm 3.18$ & $143.28 \pm 4.34$ & $141.58 \pm 1.72$ & $140.13 \pm 4.44$ & 1.900 & 0.244 \\
\hline
\end{tabular}

SEM- standard error mean, ${ }^{a b}$ Means with different superscript in a row differ significantly $(\mathrm{P}<0.05)$. 
was corroborated with the results of Goliomytis et al. (2014) and Sohaib et al. (2015) who supplied flavonoid compound in chickens at varying level with different sources and concentration of fat.

\section{Growth traits}

The data of growth traits are presented in Table 3 and 4 . The weekly body weight gain $(\mathrm{g})$ and weekly growth rate $(\mathrm{g} / \mathrm{d})$ of birds shown a significant $(\mathrm{P}<0.05)$ difference during starter phase (Table 3), however it was found comparable from $4^{\text {th }}$ to $6^{\text {th }}$ weeks and overall finisher phase. The cumulative weight gain $(\mathrm{g})$ and cumulative growth rate $(\mathrm{g} / \mathrm{d})$ was significantly $(\mathrm{P}<0.05)$ differ in each week (Table 4), which was found higher in oil supplemented group either with (T4) or without Quercetin (T3). Moreover, Quercetin supplementation also revealed higher cumulative weekly weight gain and growth rate than control group $(\mathrm{P}<0.01)$.

In agreement with the present findings, increase in weight gain and growth rate of broiler chickens was reported by Kang and Kim (2016) and Attia et al. (2020) on supplementation of rice bran oil $(5,10,20 \mathrm{~g} / \mathrm{kg})$ and canola oil $(0.5,1.5 \%)$, coconut oils $(0.5,1.5 \%)$ higher than the recommendations (BIS, 2007) in broilers, respectively. Significant $(\mathrm{P}<0.05,0.01)$ difference in weekly body weight gain $(\mathrm{g})$ and weekly growth rate $(\mathrm{g} / \mathrm{d})$ was revealed up to starter phase whereas comparable in finisher phase ( $4^{\text {th }}$ and $6^{\text {th }}$ week). It was possible due to the widening of calorie: protein ratio (Ayad et al., 2015) which favors the fat deposition in $\mathrm{T} 3$ and $\mathrm{T} 4$ during finisher phase, in contrary there was muscular growth in $\mathrm{T} 1$ and $\mathrm{T} 2$ at recommended

level of calorie: protein ratio. Quercetin as a polyphenolic compound inhibits the pathogenic bacterial flora with increased lactate organisms, thus made healthy gut environment and positively impacted on digestion of birds which might reflected in increased weight gain of birds (Sohaib et al., 2015; Hassan et al., 2018) under T2 group. Increased weight and growth rate of bird on high dietary fat might be due to the deposition of unutilized fat in abdominal region. The body fat mass (adjusted for fat-free mass) or fat deposition was positively correlated with dietary fat, saturated or unsaturated fat and age of birds (Larson et al., 2012). Moreover, saturated fat has an independent effect on body fat mass and the effect

Table 3: Effects of dietary Flavonoid (Quercetin) and vegetable oil supplementation on weekly body weight gain and weekly growth rate in broilers

\begin{tabular}{|c|c|c|c|c|c|c|}
\hline \multirow{2}{*}{ Week } & \multicolumn{4}{|c|}{ Treatment Group } & \multirow{2}{*}{ SEM } & \multirow{2}{*}{ P-Value } \\
\hline & T1 & T2 & T3 & T4 & & \\
\hline \multicolumn{7}{|c|}{ Weekly body weight gain (g/bird) } \\
\hline 2 & $219.12 \pm 3.81^{\mathrm{c}}$ & $224.67 \pm 3.64^{\mathrm{bc}}$ & $236.02 \pm 3.83^{b}$ & $237.17 \pm 3.90^{\mathrm{a}}$ & 2.599 & 0.014 \\
\hline 3 & $359.27 \pm 5.55^{\mathrm{b}}$ & $368.85 \pm 6.08^{\mathrm{ab}}$ & $370.21 \pm 5.14^{\mathrm{a}}$ & $373.07 \pm 4.76^{\mathrm{a}}$ & 2.765 & 0.066 \\
\hline Starter & $289.20 \pm 1.22^{\mathrm{c}}$ & $296.76 \pm 1.89^{b}$ & $303.11 \pm 2.09^{\mathrm{a}}$ & $305.12 \pm 1.24^{\mathrm{a}}$ & 1.769 & 0.000 \\
\hline 4 & $455.71 \pm 6.81$ & $459.18 \pm 4.164$ & $465.42 \pm 3.78$ & $453.36 \pm 4.93$ & 2.540 & 0.411 \\
\hline 5 & $584.90 \pm 6.43$ & $587.52 \pm 6.06$ & $586.50 \pm 6.98$ & $585.21 \pm 5.00$ & 2.771 & 0.989 \\
\hline 6 & $574.87 \pm 3.43$ & $570.49 \pm 7.07$ & $581.63 \pm 8.86$ & $585.90 \pm 6.28$ & 3.369 & 0.406 \\
\hline Finisher & $538.49 \pm 2.12$ & $539.06 \pm 1.28$ & $544.45 \pm 2.05$ & $541.49 \pm 2.27$ & 1.027 & 0.184 \\
\hline \multicolumn{7}{|c|}{ Weekly growth rate (g/bird/d) } \\
\hline 2 & $31.30 \pm 0.54^{\mathrm{b}}$ & $32.09 \pm 0.52^{\mathrm{b}}$ & $33.72 \pm 0.54^{\mathrm{a}}$ & $33.88 \pm 0.55^{\mathrm{a}}$ & 0.371 & 0.003 \\
\hline 3 & $51.32 \pm 0.79^{b}$ & $52.69 \pm 0.86^{\mathrm{ab}}$ & $52.88 \pm 1.46^{\mathrm{a}}$ & $53.29 \pm 0.68^{\mathrm{a}}$ & 0.395 & 0.021 \\
\hline Starter & $41.31 \pm 0.17^{\mathrm{c}}$ & $42.39 \pm 0.26^{\mathrm{b}}$ & $43.30 \pm 0.59^{\mathrm{a}}$ & $43.58 \pm 0.17^{\mathrm{a}}$ & 0.252 & 0.000 \\
\hline 4 & $65.10 \pm 0.97$ & $65.60 \pm 0.59$ & $66.46 \pm 0.54$ & $64.76 \pm 0.70$ & 0.362 & 0.331 \\
\hline 5 & $83.56 \pm 0.92$ & $83.93 \pm 0.86$ & $83.78 \pm 0.99$ & $83.60 \pm 0.71$ & 0.395 & 0.989 \\
\hline 6 & $82.12 \pm 0.49$ & $81.50 \pm 1.01$ & $83.09 \pm 1.26$ & $83.70 \pm 0.89$ & 0.481 & 0.407 \\
\hline Finisher & $76.93 \pm 0.30$ & $77.00 \pm 0.18$ & $77.78 \pm 0.29$ & $77.35 \pm 0.32$ & 0.136 & 0.181 \\
\hline
\end{tabular}

SEM- standard error mean, ${ }^{a b c}$ Means with different superscript in a row differ significantly $(\mathrm{P}<0.05)$. 
Table 4: Effects of dietary Flavonoid (Quercetin) and vegetable oil supplementation on cumulative weekly body weight gain and cumulative weekly growth rate in broilers

\begin{tabular}{|c|c|c|c|c|c|c|}
\hline \multirow{2}{*}{ Week } & \multicolumn{4}{|c|}{ Treatment Group } & \multirow{2}{*}{-SEM } & \multirow{2}{*}{ P-Value } \\
\hline & T1 & T2 & T3 & T4 & & \\
\hline \multicolumn{7}{|c|}{ Cumulative weekly body weight gain (g/bird) } \\
\hline 2 & $219.12 \pm 3.81^{\mathrm{c}}$ & $224.67 \pm 3.64^{\mathrm{bc}}$ & $236.02 \pm 3.83^{\mathrm{ab}}$ & $237.17 \pm 3.90^{\mathrm{a}}$ & 2.599 & 0.014 \\
\hline 3 & $578.39 \pm 2.45^{\mathrm{c}}$ & $593.53 \pm 3.78^{\mathrm{b}}$ & $606.23 \pm 4.19^{b}$ & $610.25 \pm 2.49^{\mathrm{a}}$ & 3.539 & 0.000 \\
\hline 4 & $1034.10 \pm 5.58^{c}$ & $1052.71 \pm 4.81^{b}$ & $1071.46 \pm 3.28^{\mathrm{a}}$ & $1063.61 \pm 3.26^{\mathrm{ab}}$ & 4.110 & 0.000 \\
\hline 5 & $1619.01 \pm 3.03^{\mathrm{c}}$ & $1640.24 \pm 4.85^{b}$ & $1657.97 \pm 3.96^{\mathrm{a}}$ & $1648.83 \pm 2.61^{\mathrm{ab}}$ & 4.079 & 0.000 \\
\hline 6 & $2193.88 \pm 4.41^{\mathrm{c}}$ & $2210.73 \pm 5.53^{b}$ & $2239.60 \pm 5.00^{\mathrm{a}}$ & $2234.73 \pm 4.57^{\mathrm{a}}$ & 5.256 & 0.000 \\
\hline \multicolumn{7}{|c|}{ Cumulative growth rate (g/bird/d) } \\
\hline 2 & $31.30 \pm 0.54^{\mathrm{c}}$ & $32.09 \pm 0.52^{b c}$ & $33.72 \pm 0.54^{\mathrm{ab}}$ & $33.88 \pm 0.55^{\mathrm{a}}$ & 0.371 & 0.014 \\
\hline 3 & $41.31 \pm 0.17^{\mathrm{c}}$ & $42.39 \pm 0.26^{\mathrm{b}}$ & $43.30 \pm 0.29^{\mathrm{a}}$ & $43.58 \pm 0 . .^{17 \mathrm{a}}$ & 0.252 & 0.000 \\
\hline 4 & $49.24 \pm 0.26^{\mathrm{c}}$ & $50.12 \pm 0.22^{b}$ & $51.02 \pm 0.15^{\mathrm{a}}$ & $50.64 \pm 0.15^{\mathrm{ab}}$ & 0.195 & 0.000 \\
\hline 5 & $57.82 \pm 0.11^{\mathrm{c}}$ & $58.58 \pm 0.17^{b}$ & $59.21 \pm 0.14^{\mathrm{a}}$ & $58.88 \pm 0.09^{\mathrm{ab}}$ & 0.145 & 0.000 \\
\hline 6 & $62.88 \pm 0.12^{\mathrm{c}}$ & $63.16 \pm 0.15^{\mathrm{b}}$ & $63.99 \pm 0.14^{\mathrm{a}}$ & $63.84 \pm 0.13^{\mathrm{a}}$ & 0.150 & 0.000 \\
\hline
\end{tabular}

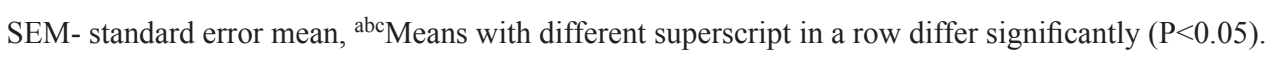

Table 5: Effects of dietary Flavonoid (Quercetin) and vegetable oil supplementation on weekly feed conversion ratio (FCR) in broilers

\begin{tabular}{|c|c|c|c|c|c|c|}
\hline \multirow{2}{*}{ Week } & \multicolumn{4}{|c|}{ Treatment Group } & \multirow{2}{*}{ SEM } & \multirow[t]{2}{*}{ P-Value } \\
\hline & T1 & $\mathbf{T 2}$ & T3 & T4 & & \\
\hline \multicolumn{7}{|c|}{ Weekly feed conversion ratio (FCR) } \\
\hline 2 & $1.56 \pm 0.05$ & $1.54 \pm 0.09$ & $1.47 \pm 0.04$ & $1.48 \pm 0.03$ & 0.029 & 0.665 \\
\hline 3 & $1.73 \pm 0.08$ & $1.67 \pm 0.03$ & $1.72 \pm 0.04$ & $1.59 \pm 0.05$ & 0.028 & 0.325 \\
\hline Starter & $1.64 \pm 0.06$ & $1.61 \pm 0.04$ & $1.60 \pm 0.02$ & $1.53 \pm 0.03$ & 0.022 & 0.409 \\
\hline 4 & $2.14 \pm 0.06^{\mathrm{a}}$ & $1.89 \pm 0.08^{b}$ & $1.94 \pm 0.03^{\mathrm{ab}}$ & $1.92 \pm 0.69^{b}$ & 0.039 & 0.045 \\
\hline 5 & $1.86 \pm 0.03$ & $1.74 \pm 0.06$ & $1.80 \pm 0.03$ & $1.77 \pm 0.07$ & 0.026 & 0.485 \\
\hline 6 & $1.89 \pm 0.01^{\mathrm{ab}}$ & $1.96 \pm 0.10^{\mathrm{a}}$ & $1.74 \pm 0.10^{\mathrm{b}}$ & $1.75 \pm 0.02^{\mathrm{b}}$ & 0.035 & 0.058 \\
\hline Finisher & $1.97 \pm 0.03^{\mathrm{a}}$ & $1.86 \pm 0.05^{\mathrm{ab}}$ & $1.82 \pm 0.01^{\mathrm{ab}}$ & $1.81 \pm 0.05^{b}$ & 0.025 & 0.049 \\
\hline
\end{tabular}

SEM- standard error mean, ${ }^{\text {ab }}$ Means with different superscript in a row differ significantly $(\mathrm{P}<0.05)$.

was greater than that of total dietary fat, which might be responsible for increased in body internal fats and ultimate higher body weight in present study, because offered extra fat contained $62 \%$ saturated fatty acids (SFA). In contrarily, Ayed et al. (2015) found significantly lower body weight on energy dense diet in chicken and suggested substantial effect of fatty acid composition significantly affect the feed consumption of birds and thereby growth performance.

\section{Feed conversion ratio}

The findings of weekly feed conversion ratio (Table 5) was found comparable up to the starter phase, however major difference $(\mathrm{P}<0.05)$ was observed during finisher phase. Supplementation of Quercetin in combination with vegetable oil (T4) performed better in respect to FCR in finisher phase.

Against the lower apparent feed intake there was increase in weight gain and growth rate on oil supplementation resulted in to the improvement of FCR. Energy sources provide an extra caloric effects (Aguiar et al., 2016), raised the net energy for utilization. Quercetin, as a flavonoid compound balancing a gut environment led to a better energy utilization efficiency.

\section{CONCLUSION}

It is concluded that inclusion of vegetable oil at $10 \%$ higher than recommendation level didn't have any impact on feed intake. Supplementation of flavonoid (Quercetin) 
or vegetable oil or in combination of both exerted better growth performance in broiler birds. Moreover, Quercetin has potential to improve gut health, therefore along with vegetable oil supplementation in diet showed improvement in feed conversion ratio of broilers.

\section{ACKNOWLEDGEMENTS}

Authors are grateful to Dean, College of Veterinary Science \& A.H., Navsari Agricultural University, Navsari-396450, Gujarat, India for providing funding and necessary facilities for this experiment.

\section{REFERENCES}

A.O.A.C. 2008. Association of Official Analytical and Applied Chemists. Official methods of analysis $18^{\text {th }}$ edition. Washington D.C. U.S.A.

Aguiar, V.D.S.L., Dourado, L.R.B., Lopes, J.B. Machado, L.P., Daphinne C.N.N.N.D., Silva, D.R.S., Santos, E.T.D. and Farias, L.A. 2016. Cotton seed oil in diets for growing broilers. Rev. Bras. de Zootec., 45(5): 208-218.

Attia, Y.A., Al-Harthi, M.A., and Abo El-Maaty, H.M. 2020. The effects of different oil sources on performance, digestive enzymes, carcass traits, biochemical, immunological, antioxidant, and morphometric responses of broiler chicks. Front. Vet. Sci., 7: 22-30.

Ayed, H.B., Attia, H. and Ennouri, M. 2015. Effect of oil supplemented diet on growth performance and meat quality of broiler chickens. Adv. Tech. Bio. Med., 4: 1-5.

BAHS, 2017. Basic animal husbandry dairying and fisheries statistics (BAHS), Ministry of Agriculture, Govt. of India, New Delhi.

BIS, 2007. Indian Standard: Poultry feed specifications, $5^{\text {th }}$ revision, Bureau of Indian Standards, New Delhi.

Duncan, D.B. 1955. Multiple ranges and multiple F' test. Biometrics, 11(1): 1-42.

Goliomytis, M., Tsoureki, D., Simitzis, P.E., Charismiadou, M.A., Hager-Theodorides, A.L. and Deligeorgis, S.G. 2014. The effects of quercetin dietary supplementation on broiler growth performance, meat quality, and oxidative stability. Poult. Sci., 93: 1957-1962.

Hassan, F.A.M., Roushdy, E.M., Kishawy, A.T.Y., Zaglool, A.W., Tukur, H.A. and Saadeldin, I.M. 2018. Growth performance, antioxidant capacity, lipid-related transcript expression and the economics of broiler chickens fed different levels of Rutin. Animals, 9: 7-11.
Kang, H.K. and Kim, C.H. 2016. Effects of dietary supplementation with rice bran oil on the growth performance, blood parameters, and immune response of broiler chickens. J. Anim. Sci. Technol., 58: 12-17.

Khatun, J., Loh, T.C., Akit, H., Foo, H.L. and Mohamad, R. 2018. Influence of different sources of oil on performance, meat quality, gut morphology, ileal digestibility and serum lipid profile in broilers. J. Appl. Anim. Res., 46(1): 479-485.

Larson, A.J., Symons J.D. and Jalili, T. 2012. Therapeutic potential of quercetin to decrease blood pressure: review of efficacy and mechanisms. Adv. Nutr., 3(1): 39-46.

Parmar, A.B., Patel, V.R., Usadadia, S.V., Chaudhary, L.M., Prajapati, D.R. and Londhe, A.S. 2019a. Influence of dietary inclusion of oil and Quercetin supplementation on carcass characters and meat quality attributes of broiler chickens. Int. J. Livest. Res., 9(9): 93-103.

Parmar, A., Patel, V., Patel, J., Usadadia, S., Rathwa, S., Prajapati, D. and Rathva, A. 2019b. Quercetin, a health promising phytoadditive for poultry production: Trends $A d v$., 8(9): $68-74$

Patane, A.S.K., Premavalli, A.V., Omprakash, J., Kirubakaran, J. and Hudson, G.H. 2017. Effect of dietary yeast supplementation on the production performance of broilers. IJABR, 7(2): 222-228

Sikder, K., Das, N., Kesh, B.S. and Dey, S. 2014. Quercetin and $\beta$-sitosterol prevent high fat diet induced dyslipidemia and hepatotoxicity in swine albino mice. Indian J. Exp. Biol., 52: 60-66.

Sohaib, M., Butt, M.S., Shabbir, M.A. and Shahid, M. 2015. Lipid stability, antioxidant potential and fatty acid composition of broilers breast meat as influenced by quercetin in combination with $\alpha$-tocopherol enriched diets. Lipids Health Dis., 14: 6165.

Yadav, R., Niyogi, D.,Tripathi, K.K., Singh, S.V. and Kumar, M. 2018. The incidence, morbidity and mortality of the diseases of broiler birds in and around Nduat, Kumarganj, Faizabad. Int. J. Curr. Microbiol. Appl. Sci., 7: 5095-5105.

Zhang, Z.F., Zhou, T.X. and Kim, I.H. 2013. Effects of dietary olive oil on growth performance, carcass parameters, serum characteristics and fatty acid composition of breast and drumstick meat in broilers. Asian-Australas. J. Anim. Sci., 26(3): 416-422. 